\title{
Penggunaan Metode SAS (Struktural Analitik Sintetik) dalam Pembelajaran Bahasa Indonesia Menulis Permulaan Siswa Sekolah Dasar
}

\section{Candra Dewi}

Universitas PGRI Madiun

candra@unipma.ac.id

\begin{tabular}{ll}
\hline Informasi artikel & \\
\hline Sejarah artikel: & \\
Diterima & 30-I I-2017 \\
Revisi & I7-04-2018 \\
Dipublikasikan & Mei 2018 \\
& \\
\hline
\end{tabular}

\section{Kata kunci:}

Metode SAS

Bahasa Indonesia

menulis permulaan \begin{abstract}
ABSTRAK
Penelitian ini bertujuan untuk mengetahui implementasi penggunaan metode SAS (Struktural Analitik Sintetik) dalam pembelajaran bahasa Indonesia menulis permulaan siswa Sekolah Dasar. Penelitian ini berupa penelitian deskriptif kualitatif. Subjek pada penelitian ini yaitu guru kelas I Sekolah Dasar dan siswa Sekolah Dasar sejumlah 20 siswa. Pada penelitian ini peneliti menggunakan teknik pengumpulan data dengan cara observasi, dokumentasi, wawancara dan tes. Teknik analisis data pada penelitian ini adalah analisis data interaktif, ada tiga hal utama dalam analisis data model interaktif yaitu reduksi data, penyajian data, dan penarikan kesimpulan. Berdasarkan pada pelaksanaan metode SAS pada mata pelajaran Bahasa Indonesia untuk melatih keterampilan menulis pada siswa kelas I Sekolah Dasar Negeri Tanjung 2 Kecamatan Bendo Kabupaten Magetan ini sudah berjaalan sesuai dengan renacan pembelajaran yang tertuang dalam RPP (Rencana Pelaksanaan Pembelajaran. Melihat dari hasil evaluasi pembelajaran yang telah diberikan, hasil menulis siswa sudah cukup baik. Nilai rata-rata kelas yaitu 8I,75 dari 20 siswa di kelas I. nilai terendahnya yiatu 70 dan nilai tertingginya yaitu 90 . Berdasarkan KKM yang sudah ditentukan yaitu 75, maka dapat disimpulkan bahwa ada 90\% siswa sudah mencapai nilai tuntas atau mencapai nilai KKM, sedangkan I0\% siswa masih belum mencapai nilai tuntas atau masih dibawah nilai KKM.
\end{abstract}

Key word:

SAS Method

Bahasa Indonesia

write the beginning

\begin{abstract}
This study aims to determine the implementation of the use of SAS (Structural Analytic Synthetic) method in Indonesian language learning to write the beginning of elementary school students. This research is a qualitative descriptive research. Subjects in this research are first grade teachers of Elementary School and Elementary School students of 20 students. In this study researchers used data collection techniques by way of observation, documentation, interviews and tests. Data analysis technique in this research is interactive data analysis, there are three main thing in data analysis of interactive model that is data reduction, data presentation, and conclusion. Based on the implementation of SAS method in Indonesian Language subjects to train writing skill in grade I students of SD 2 Negeri Bendo Subdistrict, Magetan Regency has been running in accordance with the learning plan as stated in the lesson planning plan. given the result of writing the student is good enough The average grade of 8I.75 from 20 students in class I. the lowest value yiatu 70 and the highest value is 90 . Based on the predetermined KKM that is 75 , it can be concluded that there is $90 \%$ students have achieved the value or achieved the value of KKM, while I0\% of students still have not reached the value of complete or still below the value of KKM.
\end{abstract}

Copyright (C) 2018 Universitas Ahmad Dahlan. All Right Reserved

\section{Pendahuluan}

Kemampuan menulis oleh para ahli pengajaran bahasa ditempatkan pada tingkatan paling tinggi dalam proses pemerolehan bahasa. Hal ini disebabkan kemampuan menulis merupakan kemampuan produktif yang hanya dapat diperoleh 
sesudah kemampuan menyimak, berbicara, dan membaca. Hal ini pula yang menyebabkan kemampuan menulis merupakan kemampuan berbahasa yang dianggap paling sulit. Kemampuan menulis memiliki kemampuan yang penting dalam masyarakat sepanjang zaman. Kegiatan menulis ditemukan dalam aktivitas manusia setiap hari, seperti menulis surat, laporan, buku, artikel, dan sebagainya. Dapat dikatakan, bahwa kehidupan manusia hampir tidak bisa dipisahkan dari kegiatan menulis.

Dalam pelajaran bahasa Indonesia, menulis merupakan salah satu kegiatan berbahasa yang dianggap primer. Idelanya, pelajaran bahasa Indonesia diminati karena dapat mengasah empat kompetensi berbahasa, yakni berbicara, mendengarkan, membaca dan menulis. Keempat kompetensi ini merupakan kemampuan dasar yang harus dimiliki setiap orang agar mampu menyerap informasi dan mengkomunikasikannya kembali kepada orang lain. Menurut Susanto (2013: 249) menulis pada dasarnya adalah kegiatan seseorang menempatkan sesuatu pada sebuah dimensi ruang yang masih kosong, setelah itu hasilnya yang berbentuk tulisan dapat dibaca dan dipahami isinya. Nurjamal dkk., (20II: 69) menjelaskan "menulis merupakan sebuah proses kreatif mengungkapkan gagasan dalam bentuk bahasa tulis untuk tujuan, misalnya memberi tahu, meyakinkan, menghibur".

Keterampilan menulis harus dilatih sejak dini, karena keterampilan menulis tidak dapat dikuasai dengan tiba-tiba tetapi perlu dilatih dari dini. Dengan adanyanya standar kompetensi tersebut di sekolah dasar, diharapkan peserta didik mampu menulis secara baik dan kreatif dari sejak dini. Pembelajaran membaca permulaan siswa kelas satu sudah diajarkan bentuk-bentuk huruf, baik huruf lepas ataupun huruf tegak bersambung sehingga di tingkat lanjut mereka dapat membaca dengan baik dan benar. Akan tetapi dalam pembelajaran menulis permulaan pada siswa kelas satu masih banyak yang mengalami kendala karena mereka belum berhasil menulis huruf tegak bersambung dan menggunakan huruf kapital pada awal kalimat maupun nama orang dengan sempurna sehingga mereka hanya dapat membaca kata ataupun kalimat tetapi sulit dalam menuliskan ke dalam bentuk huruf tegak bersambung.
Mengajarkan menulis bukanlah hal yang mudah. Banyak siswa kelas sekolah dasar yang kemampuan menulisnya masih rendah. Masih banyak siswa sekolah dasar yang masih kesulitan untuk menulis. Hal tersebut terjadi karena minat siswa untuk menulis masih rendah. Selain itu, tahapan berpikir siswa SD masih berada pada tahap operasional konkret. Hal itulah yang seharusnya dilakukan perbaikan pembelajaran menulis disesuaikan dengan tahap kemampuan siswa.

Menulis memiliki banyak manfaat bagi siswa. Hal itu dikarenakan dengan menulis, siswa dapat menuangkan kreativitas yang dimiliki, menumbuhkan rasa ingin tahu, dan dengan menulis siswa siswa akan menjadi lebih peka dengan lingkungan. Hal itu sejalan dengan pendapat Semi (2007:4) bahwa manfaat menulis dapat menimbulkan rasa ingin tahu (curiocity) dan melatih kepekaan dalam melihat realitas disekitar lingkungan itulah yang kadang tidak dimiliki oleh orang yang bukan penulis. Pendapat lain dikemukakan oleh Syamsudin (2005:3) berpendapat bahwa manfaat menulis yaitu membuat kegiatan yang produktif dan ekspresif sehingga tata tulis, struktur bahasa, dan kosakata dapat bermanfaat bagi penulis. Manfaat menulis dapat mamberikan pendapat, ide, dan pikiran melalui hasil tulisan.

Roy Sembel \& Vivi Juanita Sembel (2007: 28) menyatakan bahwa tujuan dari tulisan yang akan dihasilkan adalah meyakinkan pembaca, menghibur pembaca, menceritakan secara kronologis sebuah peristiwa dan menjelaskan sebuah proses. Sedangkan Ahmad Rafi'uddin dan Darmiyati Zuhdi (2002: 5455) dikemukakan langkah-langkah pengajaran menulis di kelas I dan 2 SD, yang secara garis besar dapat dikemukakan sebagai berikut; (I) Pengenalan Huruf, Pengenalan huruf dilakukan melalui langkahlangkah: a) menyajikan gambar, b) menyebut dan menulis nama yang terdapat dalam gambar, c) menggunakan teknik analisis dan sintetis dan memperkenalkan bentuk-bentuk huruf; (2) Latihan, Kegiatan yang dilakukan: a) memegang pensil dan sikap duduk, b) gerakan tangan dalam menulis: garis lurus dan setengah lingkaran, c) mengeblat: menggunakan karbon dan kertas tipis, menebalkan tulisan, d) menghubungkan titik-titik untuk membentuk huruf, dan e) menatap huruf/ kata (koordinasi mata, ingatan dan ujung jari), (3) Menyalin Tulisan, Kegiatan yang dilakukan: menyalin huruf, menyalin kata, menyalin kalimat dan menyalin bacaan sederhana. (4) Menulis Halus, 
Penekanan diarahkan pada bentuk huruf, ukuran huruf, tebal tipisnya penulisan huruf, serta kerapian tulisan; (5) Dikte/ Imla, Kegiatan yang dilakukan dalam dikte meliputi: anak menyiapkan alat tulis guru mengucapkan kalimat, anak menulis kalimat yang diucapkan guru, tulisan anak dikoreksi oleh temannya, dan anak membetulkan tulisannya; (6) Melengkapi, Kegiatan yang disarankan meliputi: melengkapi dengan huruf, melengkapi dengan suku kata, dan melengkapi dengan kata; (7) Menulis Nama, kegiatan menulis nama difokuskan pada penulisan nama benda atau gambar, nama orang, nama binatang dan nama jalan.

Salah satu metode yang digunakan untuk melatih keterampilan menulis pada siswa kelas satu yaitu dengan menggunakan metode Stuktural Analitik Sintetik (SAS). Metode SAS hampir sama dengan metode global. Namun yang membedakannya terletak pada tahapan akhirnya. Pada metode SAS kalimat yang sudah diuraikan dikembalikan seperti bentuk semula. Supriyadi (I992; I82) mengemukakan bahwa "metode SAS adalah suatu metode yang memulai pengajaran dengan menampilkan stuktur kalimat secara utuh dahulu, lalu kalimat itu di analisis dan pada akhirnya di kembalikan pada kalimat bentuk semula”.

Metode ini sejalan dengan prinsip linguistik (ilmu bahasa) yang memandang satuan bahasa terkecil yang bermakna untuk berkomunikasi adalah kalimat, bahwa pada hakikatnya kalimat merupakan suatu struktur. Oleh karena itu kepada siswa disajikan kalimat secara utuh, kemudian kalimat itu dianalisis menjadi unsur-unsur kalimat, yaitu kata, kata dianalisis menjadi suku kata, suku kata dianalisis menjadi huruf (unsure terkecil dari bahasa). Unsur terkecil berupa huruf itu, kemudian dirangkaikan kembali menjadi suku kata, suku kata dirangkai menjadi kata, dan akhirnya kata dirangkai menjadi kalimat.

Kegiatan menulis permulaan menggunakan metode SAS dilaksanakan melalui langkah-langkah sebagai berikut; (I) Guru menuliskan sebuah kalimat sederhana. Setelah itu kalimat dibaca, siswa menyalinnya; (2) Kalimat tersebut diuraikan/ dipisah-pisahkan ke dalam kata-kata. Setelah dibaca, siswa menyalin kata-kata itu seperti yang dilakukan guru; (3) Kata-kata dalam kalimat itu diuraikan lagi atas suku-sukunya. Setelah dibaca, siswa menyalin suku-suku itu seprti yang dilakukan oleh guru. (4) Suku-suku kata itu diuraikan lagi atas hurufhurufnya. Siswa menyalin seperti yang dilakukan guru; (5) Setelah guru memberikan penjelasan lebh lanjut, huruf-huruf itu dirangkaikan lagi menjadi suku kata. Siswa melakukan seperti apa yang dilakukan guru. (6) Setelah semua siswa selesai, guru merangkaikan suku-suku menjadi kata, siswa menyalin, (7) Kata-kata tersebut dirangkaikan lagi sehingga menjadi kalimat seperti semula. Siswa melakukan hal yang sama seperti guru. (Darmiyati Zuchdi dan Budiasih,200I:75)

Pendekatan yang digunakan dalam penelitian ini adalah penelitian dengan pendekatan deskriptif kualitatif. Dalam penelitian deskriptif, peneliti tidak melakukan manipulasi atau memberikan perlakuanperlakuan tertentu terhadap variabel, tetapi semua kegiatan, keadan, kejadian, aspek komponen dan variable berjalan apa adanya. Penelitian ini bertujuan untuk menganalisis kesulitan belajar membaca siswa mental retardation. Penelitian ini dilaksanakan di SDN SDN Kedungputri 2 Kecamatan Paron Kabupaten Ngawi.

Subjek dalam penelitian ini adalah kepala sekolah SDN Kedungputri 2, guru kelas 3 dan siswa kelas 3 SDN Tanjung 3 Kecamatan Bendo Kabupaten Magetan yang mengalami mental retardation bernama Ambarwati. Dalam penelitian kualitatif, yang menjadi instrumen atau alat penelitian adalah peneliti itu sendiri sehingga peneliti harus "divalidasi". Validasi terhadap peneliti, meliputi: pemahaman metode penelitian kualitatif, penguasaan wawasan terhadap bidang yang diteliti, kesiapan peneliti untuk memasuki objek penelitian baik secara akademik maupun logiknya. Peneliti kualitatif sebagai human instrument berfungsi menetapkan fokus penelitian, memilih informan sebagai sumber data, melakukan pengumpulan data, menilai kualitas data, analisis data, menafsirkan data dan membuat kesimpulan atas temuannya (Sugiono, 2009:306). Dalam penelitian kualitatif, pengumpulan data dilakukan pada natural setting (kondisi yang alamiah), sumber data primer, dan teknik pengumpulan data lebih banyak pada observasi berperan serta (participation observation), wawancara mendalam (in depth intervieu) dan dokumentasi. Teknik analisis data dilakukan dengan menggunakan teknik analisis data model interaktif. Tiga hal utama analisis data model interaktif menurut Miles dan Huberman (I992: I9-20) yaitu reduksi data, penyajian data, dan penarikan kesimpulan atau verifikasi.

\section{Metode}




\section{Jenis Penelitian}

Penelitian ini merupakan sebuah penelitian deskriptif dengan pendekatan kualitatif. Bogdan dan Taylor dalam Moloeng (2007:4) mendefinisikan penelitian kualitatif sebagai prosedur penelitian yang menghasilkan data deskriptif berupa kata-kata tertulis atau lisan dari orang-orang dan perilaku yang diamati dari fenomena yang terjadi. Lebih lanjut Moleong (2007:II) mengemukakan bahwa penelitian deskriptif menekankan pada data berupa kata-kata, gambar, dan bukan angka-angka yang disebabkan oleh adanya penerapan metode kualitatif. Selain itu, semua yang dikumpulkan berkemungkinan menjadi kunci terhadap apa yang sudah diteliti. Penelitian ini bertujuan untuk mendeskripsikan implementasi metode SAS untuk siswa sekolah dasar. Penelitian ini dilaksanakan di SDN Tanjung 2 Kecamatan Bendo Kabupaten Magetan. SD tersebut sudah melaksanakan pendidikan karakter dalam proses pembelajaran.

\section{Subjek Penelitian}

Subjek dalam penelitian ini adalah guru dan siswa kelas I SDN Tanjung 2 yang berjumlah 20 siswa. Pembelajaran yang digunakan dalam penelitian ini adalah pembelajaran Bahasa Indonesia.

\section{Teknik Pengumpulan Data}

Data merupakan bahan penting yang digunakan oleh peneliti untuk menjawab pertanyaan atau menguji hipotesis dan mencapai tujuan penelitian. Teknik pengumpulan data merupakan cara yang digunakan peneliti untuk mendapatkan data dalam suatu penelitian. Pada penelitian ini peneliti menggunakan teknik pengumpulan data dengan cara observasi, dokumentasi, wawancara dan tes. Observasi adalah pengamatan yang dilakukan dengan sengaja dan sistematis terhadap aktivitas individu atau obyek lain yang diselidiki. Dalam penelitian ini, sesuai dengan objek penelitian maka, peneliti memilih observasi partisipan yaitu teknik pengamatan dimana peneliti ikut ambil bagian dalam kegiatan yang dilakukan oleh objek yang diselidiki. Dalam teknik pengumpulan menggunakan wawancara peneliti memilih melakukan wawancara mendalam, ini bertujuan untuk mengumpulkan informasi yang kompleks, yang sebagian besar berisi pendapat, sikap, dan pengalaman pribadi, SulistyoBasuki (2006:173). Dokumen yang digunakan peneliti disini berupa foto, gambar, serta data-data mengenai pembelajaran menulis. Tes digunakan untuk mengetahui hasil dari latihan menulis siswa dengan menggunakan metode SAS.

\section{Teknik Analisis Data}

Teknik analisis data dilakukan dengan menggunakan teknik analisis data model interaktif. Tiga hal utama analisis data model interaktif menurut Miles dan Huberman (1992: 19-20) yaitu reduksi data, penyajian data, dan penarikan kesimpulan atau verifikasi.

\section{Sumber Data dalam Penelitian}

Penelitian ini menggunakan data primer dan data sekunder. Data primer yang digunakan berupa transkip hasil wawancara, pengaruh sistem penyimpanan arsip Koran suara merdeka terhadap kemudahan proses temu kembali informasinya. Dan hasil temuan-temuan saat proses pelaksanaan penelitian. Sedangkan data sekunder adalah data yang diperoleh dari teknik pengumpulan data yang menunjang data primer yang bersumber dari buku, jurnal,

\section{Hasil dan pembahasan}

Hasil penelitian dan pembahasan pada penelitian ini akan dipaparakan dalam bentuk deskriptif mengenai pelaksanaan metode SAS pada kegiatan menulis permulaan siwa kelas I Sekolah Dasar. Pada tahap awal penelitian yang dilakukan peneliti adalan melakukan observasi pada kegiatan pembelajaran menulis permulaat mata pelajaran Bahasa Indonesia di kelas I. Data yang diperoleh pada tahap observasi awal yaitu sebagi berikut:

I. Kegiatan Persiapan Pembelajaran

Awal dari pelakasaan pembelajaran adalah melakukan persiapan sebelum pelaksanaan pembelajaran di kelas. Kegiatannya yaitu menyipkan RPP (Rencana Pelaksanaan Pembelajaran) sesuai dengan metode SAS yang akan digunakan. RPP dibuat mengau pada Sandar Kompetensi dan Kompetensi Dasar pada silabus pembelajaran Bahasa Indonesia Kelas I. Tema yang dipilih yaitu pekerjaan dan hiburan, sedangkan standar kompetensi yang digunakan yaitu no 8 menulis permulaan dengan huruf tegak bersambung melalui kegiatan dite dan menyalin. Untuk kompetensi dasarnya yaitu no 8.I menulis kalimat sederhana yang didiktekan guru dengan huruf tegak bersambung. Dan indikatornya antara lain mampu menyalin kalimat ke dalam tulisan tegak bersambung, mampu menggunakan huruf capital dalam menulis nama seseorang dengan tulisan tegak bersambung, mampu menulis dike dengan tulisan tegak bersambung. Tujuan dari pembelajaran antara lain siswa dapat menyalin kalimat ke dalamtulisan tegak bersambung, siswa dapat menggunakan huruf capital dalam 
menulis nama seseorang dengan tulisan tegak bersambung, siswa dapat menulis dikte dengan tulisan tegak bersambung.

2. Pelaksanaan Pwmbelajaran di Kelas

Pelaksanaan implementasi metode SAS mata pelajaran Bahasa Indonesia Siswa kelas I ini, dilaksanakan pada hari Kamis. Pada saat pelaksanaan pembelajaran, seluruh siswa hadir yaitu 20 siswa. Guru melaksanakan pembelajaran menulis, sesuai dengan Pelaksanaan pembelajaran yang telah dibuat tahap perencanaan. Pada pelaksanaan pembelajaran terbagi menjadi tiga kegiatan, yaitu kegiatan pendahuluan, kegiatan inti, dan kegiatan penutup.

a. Kegiatan Pendahuluan

Pada kegiatan pendahuluan langkah awal yang dilakukan guru yaitu memimpin siswa untuk berdoa bersama-sama, kemudian melakukan presensi dan melakukan pengkondisian kelas yaitu meminta siswa untuk menyiapkan buku dan alat-alat tulis di atas meja. Setelah itu guru malukan apersepsi dengan mengadakan Tanya jawab mengenai pekerjaan orang tua siswa dan mengenai cita-citasiswa.

b. Kegiatan Inti

Kegiatan inti dilaksanakan setelah kegaitan pendahuluan anatara lain; langkah pertama yitu guru mulai membacakan cerita mengenai salah satu pekerjaan yang ada di sekitar kita yaitu bertani, setelah itu guru mempersiapkan media pembelajaran berupa gambar yang berhubungan dengan cerita yaitu ganbar mengenai bu tani dan kegaitan yang dilakukan bu tani. Setelah cerita selesai dibacakan dan siswa telah mengamati media yang ditunjukkan oleh guru, guru menliskan salah satu kalimat yang ada di cerita tersebut di papan tulis dengan menggunakan huruf tegak bersambung. Siswa mengamati cara guru menulis di papan tulis kemudian siswa mulai menuliskan tulisan tersebut dibuku tulis masing-masing siswa. Setelah itu guru menulis suku kata sebagai uraian dari katakata tersebut dan menuliskan huruf-huruf sebagai uraian dari suku kata. Sambil menuliskan huruf-huruf tersebut, guru juga menjelaskan kepada siswa cara menguraiakan suku kata dan huruf-huruf. Setelah itu siswa menulis huruf-huruf tersebut di buku tulis masing-masing.
Guru juga menggabungkan huruf-hirif menjadi suku kata, dan dari suku kata menjadi kata-kata. Kata-kata tersebut digabungkan menjadi kalimat. Setelah guru selesaimenuliskan dan menjelaskan, siswa menuliskan penggabungan huruf-huruf tersebut di buku tulis masing-masing. Guru tetap mengawasi dan membimbing siswa yang masih mengalami kesulitan dan menulis. Setelah itu guru memberikan LKs siswa untuk menyalin tulisan lepas ke dalam tulisan tegak bersambung. Guru tetap membimbing siswa dalam mengerjakan LKS

c. Kegiatan Penutup

Pada kegiatan penutup ini, guru memberikan ulasan singkat tentang pembelajaran hari ini. Selain itu, guru juga memberikan tanya jawab pada siswa. Kegiatan yang dilakukan guru pada kegiatan penutup yaitu siswaa bersamasama dengan guru membuat kesimpulan dari materi yang telah dipelajari.

3. Hasil Evaluasi Menulis

Pada kegiatan pembelajaran bahasa Indonesia, nilai rata-rata menulis sebesar $81,75 \%$ dari 20 siswa. Nilai terendah yang didapat siswa kelas I ini yaitu 75 dan nilai tertinggi yaitu 90. Siswa yang mendapatkan nilai 70 ada 2 siswa. Siswa yang mendapatkan nilai 75 ada 5 siswa. Siswa yang mendapatkan nilai 80 ada 2 siswa. Siswa yang mendapatkan nilai 85 ada 6 siswa. Siswa yang mendapat nilai 90 ada 5 siswa. Berdasarkan KKM yang sudah ditentukan yaitu 75, maka dapat disimpulkan bahwa ada 90\% siswa sudah mencapai nilai tuntas atau mencapai nilai KKM, sedangkan I0\% siswa masih belum mencapai nilai tuntas atau masih dibawah nilai KKM.

\section{Persantunan}

Artikel ini disusun atas dorongan dan dukungan dari berbagai pihak. Ucapan terimakasih disampaikan kepada Universitas PGRI Madiun dan teman-teman sejawat. Ucapan terima kasih juga disampaikan kepada tim editorial Bahastra Pendidikan Bahasa dan Sastra Indonesia Universitas Ahmad Dahlan yang telah memberikan ruang untuk penerbitan artikel ini. Semoga artikel ini dapat memberikan kontribusi dalam pembelajaran terutama dalam kegiatan literasi kritis. 


\section{Daftar Pustaka}

Abin Syamsuddin Makmun. (2005). Psikologi Pendidikan. Bandung: PT Remaja Rosda Karya

Ahmad Rofíuddin dan Darmiyati Zuhdi. (2002). Pendidikan Bahasa dan Sastra Indonesia di Kelas Tinggi, Malang: Universitas Negeri Malang.

Ahmad, Susanto. (2013). Teori Belajar dan Pembelajaran di Sekolah Dasar.Jakarta: Kencana Prenada Media Group.

Darmiyati Zuchdi dan Budiasih. (200I). Pendidikan Bahasa dan Sastra Indonesia di Kelas Rendah. Yogyakarta: PAS. Jakarta: Gramedia Pustaka Utama

Miles, B. Mathew dan Michael Huberman. (1992). Analisis Data Kualitatif Buku Sumber Tentang Metode-metode Baru. Jakarta: UIP.

Moleong, Lexy J. (2007) Metodologi Penelitian Kualitatif, Penerbit PT Remaja Rosdakarya Offset, Bandung

Nurjamal, Daeng, Dkk. (20II). Terampil Berbahasa. Bandung: Alfabeta.

Pratiwi, C. P. (2016). Penggunaan Media Puisi Dan Pendekatan Savi Untuk Meningkatkan Kemampuan Menulis Cerpen Siswa Kelas $V_{i}$ Sekolah Dasar. Premiere Educandum: Jurnal Pendidikan Dasar dan Pembelajaran, 5(02).

Prof. Dr. Ir. Roy Sembel, MBA dan Vivi Juanita SembelLapian.(2007). Energize Your Life.

Sugiyono.(2009). Metode Penelitian Kuantitatif, Kualitatif dan R\&D, Bandung : Alfabeta.

Sulistyo-Basuki. (2006). Metode Penelitian. Jakarta: Wedatama Widya Sastra dan Fakultas Ilmu Pengetahuan Budaya Universitas Indonesia

Supriyadi, dkk. (1992). Pendidikan Bahasa Indonesia 2. Jakarta: Depdikbud, Universitas Terbuka.

Widyaningrum, H. K. (2016). Profesionalisme Dan Etika Guru Sekolah Dasar Dalam Menghadapi Dunia Pendidikan Di Era Modern. Pendidikan Guru Sekolah Dasar SI, I(OI). 